\author{
村山長*1, 畠中伸也*2, 橋本 雅 文*3 \\ 江口透*4, 大場 史 憲*4

\section{Simulation-based Evaluation of Forward and Reverse Supply Chain} \\ Takeshi MURAYAMA*5, Shinya HATAKENAKA, Masafumi HASHIMOTO, \\ Toru EGUCHI and Fuminori OBA \\ ${ }^{* 5}$ Faculty of Dentistry, Hiroshima University, \\ 1-2-3 Kasumi, Minami-ku, Hiroshima-shi, Hiroshima, 734-8553 Japan

\begin{abstract}
This paper proposes a simulation-based approach to the evaluation of a forward and reverse supply chain which includes dismantlers and recyclers as well as manufacturers and distributors. This approach evaluates a supply chain from two viewpoints : environmental load ; and economical aspect (cost, benefit, and profitability) of every company's business included in the supply chain. To evaluate it, the approach models and simulates the material and money flows between the components (such as companies and consumers) of the supply chain. The simulation reveals: whether each of the companies' businesses is profitable; how heavy the environmental load is; whether the capacity of each company or factory is enough ; and how much capacity of a factory is required if it is planned to be built and its capacity has not been determined.
\end{abstract}

Key Words: Supply Chain, Life Cycle Engineering, Life Cycle Design, Recycling, Reuse, Life Cycle Assessment, Life Cycle Costing, Simulation, Cost/Benefit Analysis

\section{1. 緒}

現在の国際的なメガコンペティションの時代に対 処するため, 資材調達から生産・物流・販売に至るサ プライチェーンを国境を越えて最適に設計・管理する ことが求められている.これまで, この最適性の評価 基準としてサプライチェーンによって生み出される価 值の最大化や費用の最小化が用いられることが多かつ たが, 最近では, ISO14000, 環境法, 企業や消費者 の環境に対する意識の高まりなどから, サプライチェ 一ン全体が環境に与える影響を考慮に入れる必要性が 出てきた. さらに, 最近では, take-back 法や循環型 社会の必要性から, 資材調達劫ら販売に至る順工程だ けでなく, 製品を使用した後のリサイクルやリユース といった逆工程も含めたサプライチェーン（以下では, 統合サプライチェーンと呼ぶ) を対象に，最適な設 計・管理を行なう必要も認識されている.

本論文では, このような統合サプライチェーンを

* 原稿受付 2005 年 3 月 17 日.

*1 正員, 広島大学歯学部 ( 734-8553 広島市南区霞 1-2-3).

$* 2$ 広島大学大学院工学研究科 $[$ 現: 松下電器産業 $($ 株) ].

*3 正員, 同志社大学工学部( 610-0321 京田辺市多々羅都谷 1-3).

*4 正員, 広島大学工学研究科( - 739-8527 東広島市鏡山 1-4 1).

E-mail : murayatk@hiroshima-u.ac.jp
設計するための評価方法を提案する.この方法では， 統合サプライチェーンにわたる物と金銭の流れをシミ ユレーションすると共に, 物の流れによって引き起こ される環境負荷 (環境に与える影響) を調べることに より, 統合サプライチェーンを経済性と環境負荷の両 面から評価する，また，本論文では，応用例として， この方法を製品の分解工場の配置計画に適用した例も 示す.

なお, 関連する研究として, 一階らめのサプライチ エーンのシミュレーションの研究がある. しかし, こ の研究では, 本研究で扱う逆工程やサプライチェーン が及ぼす環境負荷を考えていない，また，梅田らき， 下村らや高田らせのライフサイクルシミュレーショ ンの研究も関連研究として挙げることができる. また, Jiang と Shu らのリマニュファクチャリングの研究(5)( もライフサイクルシミュレーションの研究と考えるこ とができる. これらの研究では，製品のライフサイク ルに渡る物の流れをシミュレーションしているが，本 研究のようなサプライチェーンやそれに含まれる企業 を評価するものではない，また，筆者らもこれまでラ イフサイクルシミュレーションの研究(クい1をを行なって きたが，本研究は筆者らのこれまでの研究の拡張であ 




Fig. I Supply chain model

る.これまでの筆者らの研究との大きな違いはサプラ イチェーンの各構成要素（企業や消費者など）の地理 上の位置を考慮に入れた点である. これによる効果に ついては, 22節で説明する.

\section{2. サプライチェーンモテル}

\section{1 モデルの概要}

シミュレーションに用いるサプライチェーンのモ デルは, 図1のように, サプライチェーンの構成要素

（企業，工場，製品の消費地，最終処分場など）ごと にモジュール化されており，モデルには構成要素内お よび構成要素間の物の流れ（Material flow）と金銭の 流れ（Money flow），およびこれらの流れの管理

(Flow control) がカラーペトリネットにより表現され

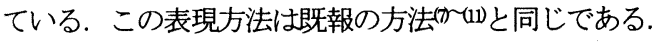
以下では, その概要を述べる.

図1のように，モデルはプレース，トークン，ト ランジションから構成され, これらの持つ意味は Material flow, Money flow, Flow controlによってそれ ぞれ異なる.

Material flow では，プレースは物の状態を表し，プ レース内のトークンはその状態に物（部品や製品な ど）が存在することを表している. トランジションは 「加工する」などの状態間の遷移を表し，遷移に要す る時間 (加工時間など) と発火規則（状態遷移を起こ す条件など）がこれに記述される．状態が遷移するこ とを発火するといい，発火が起こるとトークンが移動 する. たとえば, 図 1 でトランジション $\mathrm{t} 1$ が発火す ると, このトランジションの右側のプレースにあるト 一クンがトランジションの左側のプレースに移動する.
これは，そのトークンを表す物が右側のプレースの示 す状態から左側のプレースの示す状態に遷移したこと を表す。このような発火を次々と起こすことにより， サプライチェーンにわたる物の流れをシミュレーショ ンできる.

Money flow では, プレースは収支に関わるデータ の種類（収入データ，支出データ）を表し，トークン にはその金額が記述される. トランジションは「支払 う」などの金銭データの処理を表す. サプライチェー ンの構成要素間の金銭の受け渡しは，金額が記述され たトークンの移動によりシミュレーションできる.

Flow control では, プレースは在庫管理などのため に必要なデータの種類を表し, トークンにはそのデー 夕の内容（在庫量や納入量など）が記述さる. トラン ジションは「発注する」などのデータ処理を表す。サ プライチェーンの構成要素間の物の流れやそれに伴う 金銭の受け渡しは，この「発注する」などのトランジ ションの発火に伴って起こる.

\section{2 追加情報}

今回，新たに以下の情報もモデルで扱うようにし た.

1) サプライチェーンの各構成要素の地理上の位置

2）サプライチェーンの構成要素のキャパシティ（た とえば, 工場の場合, 月当たりの最大処理能 力)

3）各地域における労働コスト，地代などのコスト

4）製品の消費地の人口

以上のうち，1）の位置を考慮に入れることによ り, 地域環境問題（各地域での廃亯物の量など）を地 球環境問題（地球温暖化など）と区別し，地域環境問 題についてはサプライチェーンの各構成要素がそれが 存在する地域でどの程度影響を及ぼすかを把握できる ようになる. さらに, サプライチェーンの構成要素間 の距離をこの位置情報を基に算出でき，また，その距 離を用いて物の輸送に要する時間とコストも計算でき るようになる。

また，2）の各構成要素のキャパシティを考慮に 入れてシミュレーションすることにより, 各構成要素 でそのキャパシティを超える処理要求が起こらないか が分かる. なお，ある工場を新規に建設するような場 合は，予めそのキャパシティを設定するのではなく， シミュレーションによりその工場の適切なキャパシテ イを決定することになる.これについては，4 章でそ の例を示寸。 


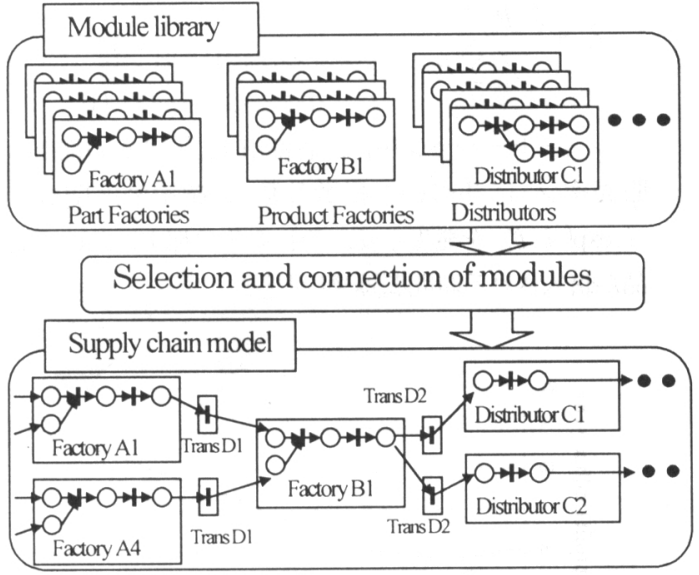

Fig. 2 Modeling by the building block method

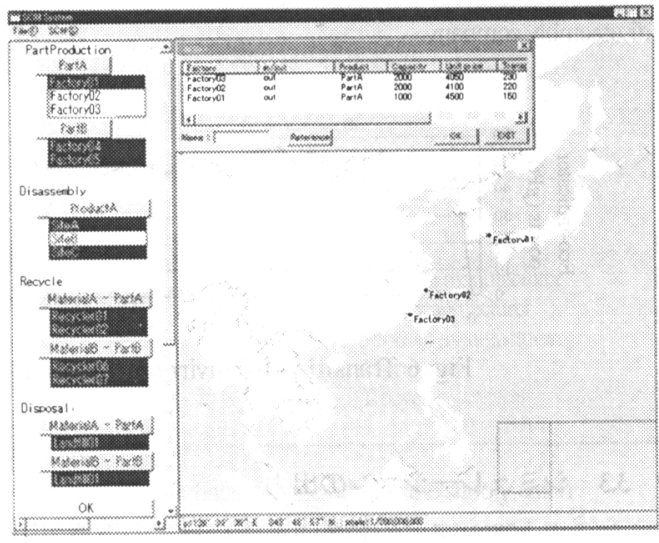

Fig. 3 An example of window when an operator selects some modules

また，3）により，地域によるコストの相違を考 慮できる．さらに，4）の製品の消費地の人口を扱う ことにより, 都市の人口による製品の需要量の相違を 考慮に入れることができる. 現在のところ人口が 100 万人以上の主要都市でのみ製品の需要があるものとし ている.

\section{3. モデリングとシミュレーション}

\section{1 モデリング}

モデリング方法は既報の方法(か (11) とほぼ同じであ り, 図2のように, ビルディングブロック法によりモ デリングを行なう. すなわち, 予めサプライチェーン の構成要素の種類（素材製造工場, 部品製造工場, 製 品製造工場，流通会社，製品の消費地，集荷場，分解
工場, リサイクル工場, 最終処分場) ごとにモジュー ルの候補を用意しておき，その中からモジュールを選 択し結合することにより，モデルを構築する.

既報の方法と異なる点は, 各構成要素の種類に対 して複数の候補を選択できる点である.たとえば，あ る部品の製造工場として複数の工場を選択できる.こ の場合, 選択した複数の候補に部品の発注量を配分す る必要があるが，ここでは，才ペレータが各候補に対 する配分割合を決めることにした.

また，今回，新たに，モデリング時に図 3 に示す ようなウインドウを表示するようにした：これにより， オペレータは, モジュールの各候補の位置, キャパシ ティ, 扱っている商品の単価, などの情報を参照して, モジュールを選択できる. この図で，左側の黒い部分 が選択されたモジュールを表す．モジュールの選択が 終わると，オペレータが各モジュールを接続し，モデ ルを完成させる，また，各モジュールの地理上の位置 を基に，サプライチェーンの構成要素間の輸送距離が 自動的に計算される．ただし，ここでは構成要素間の 直線距離を輸送距離とした。ささらに，この輸送距離を 用いて，輸送時間（二輸送距離×単位距離当たりの輸 送時間），1回当たりの輸送コスト（=輸送距離×単 位距離当たりの輸送コスト）が計算され，輸送のモジ ュールにこれらの情報が追加される．

\section{2 シミュレーション}

シミュレーション方法も既報の方法(か (1) と基本的 には同じであり，物や金銭を表すトークン（図10黒 丸）をモデル上で次々と動かすことにより物と金銭の 流れをシミュレーションする.

このシミュレーション中に, 物の流れに伴って発 生する環境負荷も計算するが，この方法も既報(8)(100の 方法と同じである.これは，モデルの Material flow 部 でトランジションが発火し，物を表すトークンが移動 するごとに，その移動が表す状態㖶移に伴う噮境負荷 を LCA(Life Cycle Assessment)の手法により計算するも のである. 図 4に, 部品の加工を例にした, シミュレ ーション中の計算の概要を示す. トランジション（図 4 では部品の加工を表す Machining) が発火すると, トランジションに記述されたデータ (加工の種類, 加 工時間など，トランジションによって異なる）と分析 用データベースをもとに, 発火（物の状態遷移）に伴 う環境への排出物の量と投入資源の量が計算される. この計算は, トランジションが発火する(図4では部 品が加工される）たびに行われるが，その結果は $\mathrm{CO} 2$ や $\mathrm{NOx}$ などの項目別に積算され，一定時間ごと 


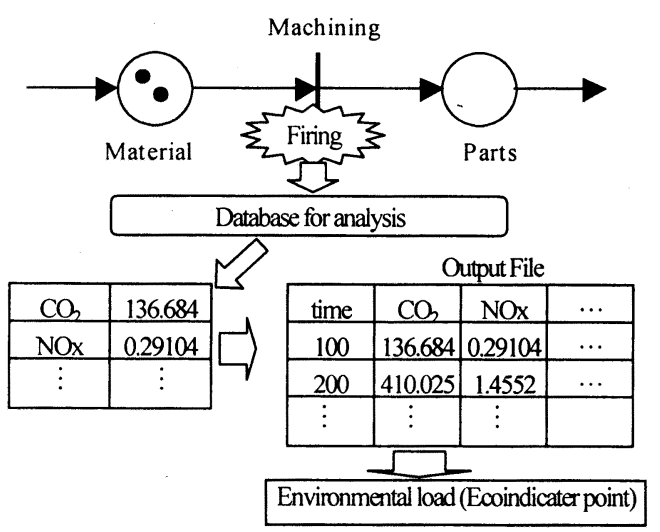

Fig. 4 LCA during Simulation

に，その時間までの積算値が項目別に結果ファイルに 記録される. そしてこの結果ファイルを基に環境負荷 を計算する。本研究では，環境負荷として Eor indicator point ${ }^{(138}$ を計算している.

また，サプライチェーンを経済面で評価するため, シミュレーション中に以下に示寸売上, 支出の計算が モジュールごとに既報のの方法で行われる.

（1）物の売買に伴う売上と支出: モジュール間で物 の受け渡しがある毎に，そのモジュールが得る売上や 支払う費用が計算される。

（2）部品などの処理費用: 製造などの処理に関連す るトランジション (図40 machining など) が発火す ると, 処理量と単位処理コストから処理費用が算出さ れる.

（3）固定費用：1 月おおに1ヶ月分の固定費用 （人件費を含む）がモジュールの支出額に追加される.

（4）材料などの保管費: 倉庫を表すプレースが持つ 保管量のデータをもとに月ごとの保管費が計算される.

これらの売上, 費用はモジュールごとに記録され, これらを基にそのモジュールの利益が計算される.

以上のように，シミュレーション方法は既報の方 法とほとんど同じであるが，既報の方法と異なる点は， 都市ごとに人口の相違を考慮に入れて製品の需要を与 える点である. その方法を以下に示す. まず, シミュ レーションを始める前に, オペレータが各期（たとえ ばーヶ月）ごとに販売率入（単位期間当たりの製品の 販売個数）を設定する. 次に各都市 $i(i=1,2, \ldots, \mathrm{N})$ の 人口 $P_{i}$ を基に，各都市 $i$ における販売率 $\lambda_{i}$ を次式で決 定する.

$$
\lambda_{1}=\lambda \cdot P_{i} / \sum_{i=1}^{N} P_{i}
$$

シミュレーション中は, 各都市 $i$ ごとにその都市の 販売率 $\lambda_{i}$ に基づいて指数乱数（確率密度関数は $\lambda_{i} \exp \left(\lambda_{i} \partial\right)$ を発生させ，それをその都市において製 品が購入される時間間隔(22とする.

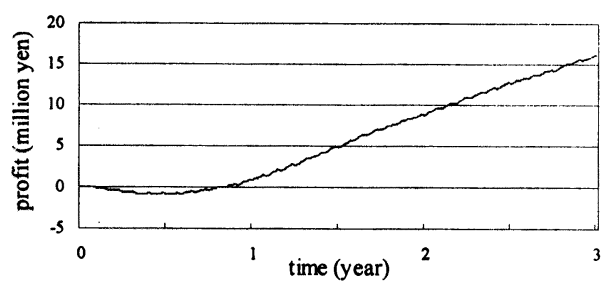

Fig. 5 Transition of accumulated profit (=sales - costs) in a disassembly company



Fig. 6 Transition of environmetal load

\section{3 シミュレーションの出カ}

シミュレーションの結果として, 以下の情報を出 力できる.

（1）サプライチェーンに含まれる各会社の売上，コ スト, 利益（=売上ーコスト），およびそれらの時間 に伴う変化. コストは 3.2 節で示した(1)〜(4)の項目毎 に出力できる.

（2）環境負荷 (Ecoindicator point)，項目（図40 $\mathrm{CO}_{2}, \mathrm{NOx}$ や図 7 の $\mathrm{BOD}$ (水質污染) など) 毎の環境 負荷, およびこれらの工程（輸送, 部品製造など）毎 の内訳. さらに, これらの時間に伴う変化.

（3）県別, 地方別の地域環境問題に対寸る環境負荷 およひ項目毎の環境負荷.

（4）各会社で処理される部品や製品の数（単位期間 毎に出力).

図 5，6，7に出力結果の例を示す.ただし，この 結果は, 製造会社, 製品の消費地 (人口 100 万人以上 の都市) , 分解会社, リサイクル会社, および流通会 社からなるサプライチェーンを対象にシミュレーショ ンを行なった結果であり，このサプライチェーンの製 

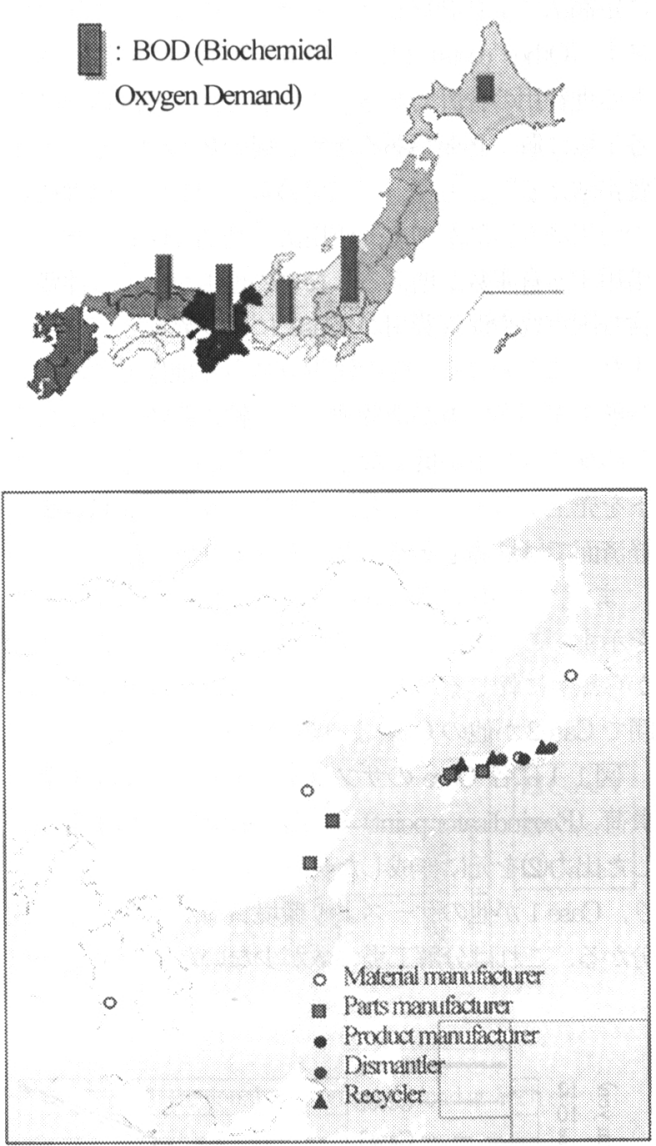

Fig. 8 Factories included in the supply chain

造会社, 分解会社, リサイクル会社の地理上の位置は 図8のとおりである. 図5は(1)のうち利益の時間変化 の出力例である. ただし，これは利益の積算の変化を 示しており，この図のような利益変化をグラフ化する ことにより，“分解会社は 10 ケ月頃から黒字に転じ る”と言ったようなことが把握できるようになる。ま た，図6は(2)のうち環境負荷の時間変化の出力例であ る.なお,この図て環境負荷が変動しているのは, 製 品の製造が連続的に行なわれるのではなく, 在庫があ る值を下回った時にある量だけ製造するためである。

図6のような出力により,“1年半頃からリサイクル の効果により環境負荷が下がる”といったようなこと も把握できるようになる．なお，これは， 1 年半頃か ら使用済みになる製品が増加し，それをリサイクルす ることにより得られる再生材を活用することにより, 資源の消費が減少したためである. また，本手法では サプライチェーンの構成要素の地理上の位置を考慮に 入れているため, 地域環境問題を地球環境問題と区別

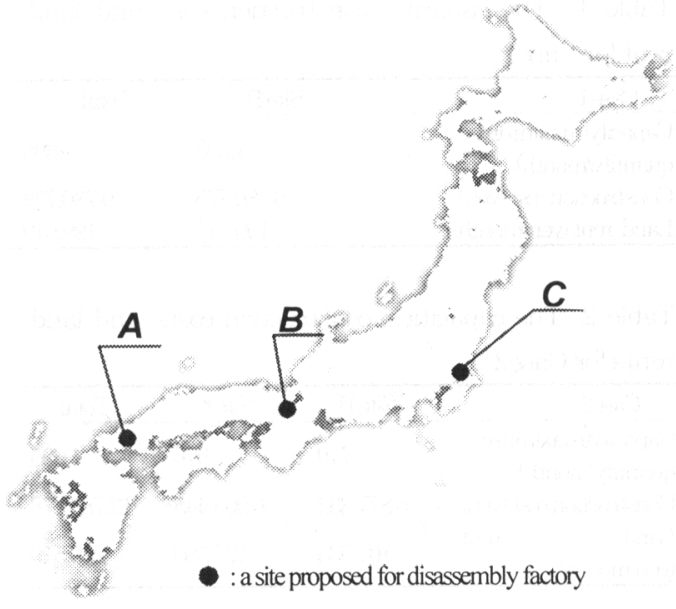

Fig. 9 Sites proposed for disassembly factories

して出力でき, 図7のように，地域環境問題（図7で は BOD) については各構成要素が地域でどの程度影 響を及ぼすかを把握できる。

\section{4. 分解工場の配置計画への応用}

ここではサプライチェーンの構成要素のうち分解工場 以外は決定済みとし，新たに分解工場を建設する場合 を対象にシミュレーションを行なった. 分解工場以外 の構成要素は 3.3 節の例と同じに設定した，今，

これらのうちのいくつかの場所に建設するものと

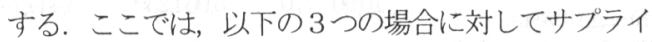
チェーンのシミュレーションを行なった.

Casel : 分解工場を B の場所の夕に建設寸る場合

Case2 : 分解工場を B およびC に建設する場合

Case3 : 分解工場を A, B , C の 3 ケ所に建設する 場合.

また，各都市で排出される使用済み製品はその都 市に最も近い分解工場に運搬されるものとした

以上の 3 つの Case に対してそれぞれモデルを作成 し, 物と金銭の流れのシミュレーションを行なった。 その結果, 各 Case における各分解工場に要求される キャパシティは表 1 〜のようになった. このキャパ シティは，分解工場で各期間に処理される使用済み製 品数（3.3 節で示した出力(4)により得られる数）の最 大值である. また，このキャパシティを基に建設コス 卜と地代を計算した，その結果も表 1 ～3に示してい る.ただし，単位面積当たりの地代は建設候補地によ 
Table 1 The capacity, construction cost, and land rent for Case 1

\begin{tabular}{lrr}
\hline \multicolumn{1}{c}{ Case1 } & \multicolumn{1}{c}{ SiteB } & \multicolumn{1}{c}{ Total } \\
\hline Capacity(maximum & 1,695 & 1,695 \\
quantitymonth) & $9,780,778$ & $9,780,778$ \\
Constructioncost(yen) & 199,519 & 199,519 \\
Land rent(yen/month) & & \\
\hline
\end{tabular}

Table 2 The capacities, construction costs, and land rents for Case2

\begin{tabular}{lrrr}
\hline \multicolumn{1}{c}{ Case2 } & \multicolumn{1}{c}{ SiteB } & \multicolumn{1}{c}{ SiteC } & \multicolumn{1}{c}{ Total } \\
\hline $\begin{array}{l}\text { Capacity(maximum } \\
\text { quantity/month) }\end{array}$ & 719 & 976 & 1,695 \\
$\begin{array}{l}\text { Construction cost(yen) } \\
\text { Land rent } \\
\text { (yen/month) }\end{array}$ & $101,877,333$ & $6,903,445$ & $12,780,778$ \\
\hline
\end{tabular}

Table 3 The capacities, construction costs, and land rents for Case 3

\begin{tabular}{lrrrr}
\hline \multicolumn{1}{c}{ Case3 } & SiteA & SiteB & SiteC & Total \\
\hline $\begin{array}{l}\text { Capacity } \\
\text { (maximum }\end{array}$ & 218 & 501 & 976 & 1,695 \\
$\begin{array}{l}\text { quantity/month) } \\
\text { Construction oost }\end{array}$ & $3,874,778$ & $5,002,555$ & $6,903,445$ & $15,780,778$ \\
(yen) rent & 51,869 & 80,064 & 127,586 & 259,519 \\
$\begin{array}{l}\text { Land ren/month) } \\
\text { (yent) }\end{array}$ & & & & \\
\hline
\end{tabular}

Table 4 Total balance in every case after 3 years (yen)

\begin{tabular}{|c|c|c|c|}
\hline & Case1 & Case2 & Case3 \\
\hline Sales through 3 years & $87,347,260$ & $91,200,440$ & $91,010,460$ \\
\hline Depreciation for 3 years & $2,934,233$ & $3,834,233$ & $4,734,233$ \\
\hline $\begin{array}{l}\text { Land rent through } 3 \\
\text { years }\end{array}$ & $7,182,684$ & $8,262,684$ & $9,342,684$ \\
\hline $\begin{array}{l}\text { Transportation cost } \\
\text { through 3years }\end{array}$ & $10,907,770$ & $5,064,230$ & $3,444,140$ \\
\hline $\begin{array}{l}\text { Fixed oost including } \\
\text { personnel cost through } \\
3 \text { years }\end{array}$ & $28,001,221$ & $32,243,015$ & $36,012,450$ \\
\hline $\begin{array}{l}\text { Storage oost through } 3 \\
\text { years }\end{array}$ & $8,999,512$ & $6,615,099$ & $3,068,580$ \\
\hline $\begin{array}{l}\text { Other oosts through } 3 \\
\text { years }\end{array}$ & $23,006,131$ & $23,016,982$ & $22,414,326$ \\
\hline $\begin{array}{l}\text { Total balance after } 3 \\
\text { years }\end{array}$ & $6,315,709$ & $12,164,197$ & $11,994,047$ \\
\hline
\end{tabular}

り異なるように設定し, 土地はレンタルを想定した. これらの表より建設コストと地代だけを見た場合，分 解工場の数が多いほど費用がかかることが分かる.

分解工場の 3 年間の操業で得られる売上と必要な コストをシミュレーションにより求めた結果を表 4 に 示す.この表 4 で, 減価償却費 (Depreciation) と地 代は表 1 〜 3 をもとに，また，乙れ以外の項目は 3.3 節で示した出力(1)により得られる。 なお，減価償却費 は，設備の耐用年数を 10 年とし，建設コストをもと
に定額法により計算した。 また，この表でその他のコ スト（Other costs）は，使用済み製品の引き取り費用 と処理費用の合計である。この表で，“経理担当者を 各工場に置く必要があるため工場の数が増えると人件 費が増える”ことや，“工場の数が少ないと処理待ち の使用済み製品が増え，使用済み製品の保管のために 借用する倉庫数が増える”などの理由から，人件費を 含む固定費や保管費用が Case により異なってくる. またここの表より，先の建設コストや地代とは逆に， 分解工場が多い方が消費地からの輸送距離が短くなる ため輸送コストが低くなることが分かる．全てのコス 卜を売上から差し引くと，3年間の操業では Case2 が 経済面では最適であることが表 4 より分かる.

また, 図 10 に各 Case におうける利益の積算の変化 を示す.この図から，いずれの Case も 1 年 2 ケ月頃 から黒字に転じることが分かる。また，ほとんどの期 間で Case2が他の Caseより良いことが分かる.

図 11 に各 Case のサプライチェーンが及ぼす環境 負荷 (Eco-indicator point) の工程毎の内訳（3.3節で示 した出力(2)を元に作成したグラフ）を示す。この図よ り，Case 1 が他のケースより環境負荷が大きいことが 分かる. これは分解工場の数が少ないため, 他のケ一



Fig. 10 Transition of accumulated profit (=sales - costs) in a disassembly company

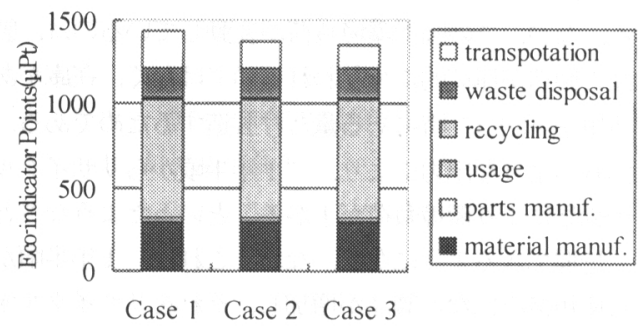

Fig. 11 Environmental load given by the supply chains 


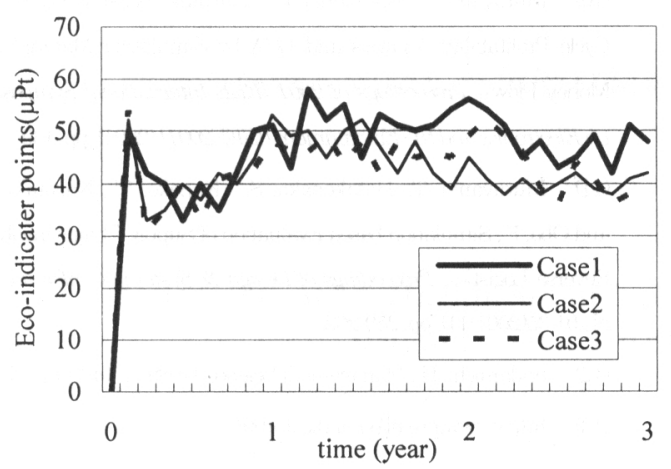

Fig. 12 Transition of environment load

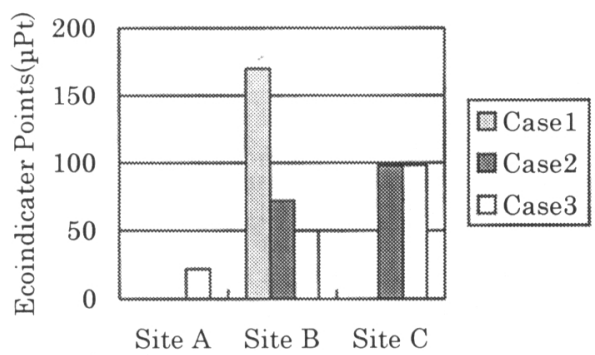

Fig. 13 Regional environmental load at each site

スより消費地から分解工場までの輸送距離が長くなり， それに伴う環境負荷が大きくなったためである。 なお， ここでは製品の組立と分解は手作業を想定したため, それらに伴う環境負荷は0 となっている.

図 12 に時間に伴う環境負荷の変化を示寸. 3.3 節 で述べた理由によりかなりの変動はあるが，ほとんど の期閒で Case1 の環境負荷が他の Case のものより大 きいことが分かる.

また, 図 13 に, 分解工場の建設候補地における 地域環境問題に対する環境負荷（3.3 節で示した出力 (3)を元に作成したグラフ）を示す。このような地域環 境問題に対する結果は，新規に工場を建設する場合， 地域住民に対寸る地域環境への影響の説明のために用 いることができると思われる. なお，図１3 で示した 環境負荷は図 11 の環境負荷のうち分解工場が関係寸 る部分を抜き出し，それを地域ごとに分けたものであ る. 地域の条例などによりこの上限が規定されている ような場合は，そのことを考慮に入れて図13をもと に工場の建設候補地を選択寸る必要がある。しかし， 今回はこのような規定がないものとすると, 図 11 か
ら判断して, Case1 の環境負荷が他より大きく, Case2 と Case3 の差は非常に小さいことから, Case2 または Case3が環境負荷の観点からは適切と判断でき る.さらに, 先に示した経済性も考慮に入れると, Case2が適切であるといえる.

なお，図10，12 に示した利益や環境負荷の時 間変化は, 今回の分解工場の配置の決定には特には影 響を与えないが，このような計画を行う人が時間変化 を把握できることは 3.3 節で述べたように有用である と思われる。

\section{5. 結 論}

本報では，統合サプライチェーンを適切に設計す るための評価方法を提案した．この方法は，統合サブ ライチェーンにわたる物と金銭の流れをシミュレーシ ヨンすると共に，物の流れに伴う環境負荷を調べるこ とにより, 統合サプライチェーンを経済性と環境負荷 の両面から評価するものである. また，本報では，こ の方法を応用することにより, 製品の分解工場の配置 とキャパシティを決定できることも示した.

なお，本手法では経済性と環境負荷を別々に評価 したが，今後はこれらの評価を統合する指標を検討す る必要がある.

\section{参考文献}

(1) Ikkai, Y., Goossenaerts, J., and Komoda, N., A simulation method for evaluating product family supply chain, Proceedings of 7 th International Conference on Emergent Technology and Factory Automation, (1999), pp.1437-1441.

(2) Nonomura, A., Tomiyama, T., and Umeda, Y., Life Cycle Simulation for Inverse Manufacturing, Proceedings of 6th International Seminar on Life Cycle Engineering, (1999), pp. 304-313.

(3) Tanaka, G., Sakai, N., and Shimomura, Y., Development of Pluggable LCA System, Proceedings of EooDesign2003, (2003), pp.687-691.

(4) Takata, S., Kimura, T., Life Cycle Simulation System for Life Cycle Prooess Planning, CIRP Annals, Vol.52, No.1, (2003), pp.37-40

(5) Jiang, Z., Shu, L, and Benhabib, B., Steady-State Reliability Analysis of Repairable Systems Subject to System Modifications, Transactions of the ASME Joumal of Mechanical Design, Vol.121, No.4, (1999), pp.614-621.

(6) Jiang, Z., Shu, L, and Benhabib, B., Reliability Analysis of Non-Constant-Size Part Populations in Design for Remanufacture, 
Transactions of the ASME Journal of Mechanical Design, Vol.122, No.2, (2000), pp.172-178.

(7) Murayama, T., Hatakenaka, S., Namito, M, and Shu, L, Modeling and Simulation of Products' Life Cycles using Petri Nets, International Journal of Japan Society for Precision Engineering, Vol.33, No.4, (1999), pp. 373-375.

(8) Hatakenaka, S., Murayama, T., Narutaki, N., and Oba, F., Simulation-Based LCA, Proceedings of The 4th International Conference on EcoBalance, (2000), pp.157-160.

(9) Hatakenaka, S., Murayama, T., Narutaki, N., and Oba, F, Cost-benefit Analysis of Recycling by Life-cycle Simulation, Transactions of the Japan Society of Mechanical Engineers, Series A, Vol 67, No. 660, (2001), pp.338-344.
(10) Murayama, T., Hatakenaka, S., Narutaki, N., and Oba, F., Life Cycle Profitability Analysis and LCA by Simulating Material and Money Flows, Proceedings of 2001 IEEE International Symposium on Electronics and the Environment (SSEE2001), (2001), pp. 139-144. (11) Murayama, T., Hatakenaka, S., Kaneko, M., Narutaki, N., and Oba, F., Simulation-based Evaluation of Supply Chains involving Reverse Logistics, Proceedings of Design \& Systems Conference '01, No.01-35(2001-11), pp. 259-262.

(12) Sadamichi, H., Management Scienœe, (1989), p.140, Ohmsha.

(13) http:/www.pre.nV/eco-indicator99/ 